\title{
Katja Jeznik \\ SOCIAL IMAGES OF YOUTH AS A CHALLENGE FOR MENTORING WORK
}

(c) (1) (1)

\begin{abstract}
The article examines the image of youth participating in vocational education and training in Slovenia, and discusses the importance of that image in understanding the role of mentors in practical training. We begin by examining the image of youth as a group and then proceed to the image of vocational school students. The image of youth both as a group and as the subgroup of students in vocational education seems to split in several directions. On the one hand, young people are seen as the rescuers of problems of the so-called Western society, while on the other hand they are understood as the problem and viewed as disinterested, narcissistic and egoistic, an image further extended, in the case of students enrolled in vocational education, to describe them as incompetent, undisciplined, lacking manners, having low motivation and lacking responsibility. Students in vocational schools are significantly different from their peers when it comes to academic success and this difference can be interpreted as a consequence of the students' environment. The present system of vocational education does not minimize the discussed difference, but instead actually reproduces and deepens it.
\end{abstract}

Keywords: youth, image of youth, vocational education and training

\section{DRUŽBENE PODOBE O MLADIH KOT IZZIV ZA MENTORSKO DELO - POVZETEK}

$V$ prispevku je obravnavana podoba o mladih, ki se vpisujejo v poklicno izobraževanje v Sloveniji, $v$ ospredju je pomen te podobe za razumevanje dela mentorja dijakom na praktičnem usposabljanju pri delodajalcu. Najprej je tematizirana podoba o mladih na splošno, nato pa je obravnavana podoba o dijakih poklicnih šol. Tako za mlade na splošno kot specifično za dijake poklicnih šol velja, da je razumevanje mladih razpeto $v$ več smeri. Po eni strani so razumljeni kot rešitelji problemov, s katerimi se srečuje tako imenovana zahodna družba, po drugi strani pa kot problem, ker naj bi bili nezainteresirani, narcistično in egoistično orientirani, kar se pri podobi o dijakih poklicnih šol dodatno utrjuje skozi pojme kot: nesposobni, nedisciplinirani, nevzgojeni, nemotivirani in neodgovorni. Dijaki poklicnih šol se po učni uspešnosti pomembno razlikujejo od svojih vrstnikov, ta razlika pa je lahko interpretirana kot posledica okolja, iz katerega prihajajo. Trenutna oblika poklicnega izobraževanja teh razlik med dijaki ne zmanjšuje, ampak reproducira in dodatno utrjuje.

Ključne besede: mladi, podoba o dijakih, poklicne in strokovne šole

Ph.D. Katja Jeznik, Faculty of Arts, University of Ljubljana, katja.jeznik@ff.uni-lj.si 


\section{INTRODUCTION}

The article examines the image of youth in the vocational education in Slovenia. Since vocational education includes practical training at work (PTW), while the responsibility for vocational training is divided between educational organizations and employers, it is important for mentors ${ }^{1}$ to be appropriately trained, as they are the ones who help with the realization of goals of educational programmes. Different programmes of mentor training (compare: Usposabljanje mentorjev dijakom oziroma študentom ..., 2016; Usposabljanje mentorjev PUD in PRI, 2012) that were designed to include familiarization of mentors with the legislation, ways of preparing documentation for appropriate planning, implementation and evaluation of mentoring students, are generally aimed at the familiarization of mentors with core developmental-psychological needs of adolescents and pedagogical-didactical characteristics of learning and teaching outside of the school environment. Less attention is given to the meaning of various images of students whom mentors take on the PTW.

The aim of the article is to argue the importance of images of youth for the pedagogical process. Social construction of youth has an important influence on the organization of educational activities that deal with youth and younger adults participating in formal, as well as informal education, such as project learning for young adults. We were interested, first, in the general image of adolescents and then in the specific image of students who decide to enrol in vocational education. We attempt to answer the question by first defining youth as a social construct, presented through various perspectives. The second part of the article shows how general images of youth are mirrored in the image of students enrolled in vocational education. We are going to highlight the specific nature of the latter image, and then proceed to evaluating the general image of students enrolled in professional and vocational schools, based on the evaluation of both teachers and students, followed by an outline of their values. The final part of the article evaluates the final suggestions for changes in the vocational education in Slovenia.

\section{SOCIAL CONSTRUCTION OF YOUTH}

The images of students enrolled into the vocational education and training that we present in this article, are informed by the assumption of youth as a social construct (Dolby and Rizvi, 2008; Ule, 2008; Boyden and Bourdillon, 2014). The latter stems from the realization that understanding youth as both a life stage and a group is related to the social factors, perception of youth, goals of socialization, and education etc., while social construction of youth at the same time helps to changes in the process of socialization and education. Cultures in various historic periods held different views and explanations of the processes of growing up, and organized the education according to those views (Dolby and Rizvi,

1 A student's mentor at a time of the practical training at work, based on the Zakon o poklicnem in strokovnem izobraževanju (2006), is defined as an employee, with the employer possessing the required training in the profession that the student is studying for. 
2008). The opposite holds true as well. Schools are the ideological apparatus of the state (Althusser, 2000) and ideology is ever-present (e.g. Apple, 1992; Schiro, 2013; Kodelja, 2014), since it represents an imaginary relationship between the individuals and their actual existential situation (Althusser, 2000). It is important to recognize the different ways in which ideology may be reproduced at school functioning as a social institution - only then can we reduce its unreflected influence (negatively influencing the set goals). We continue to propose several ways of understanding the different views of youth and young people in the light of the discussed ideological pressures.

\section{IMAGES OF YOUTH}

Images of youth as a group and as a life stage can be traced back to the beginning of Western civilisation. Around 700 B. C., Heziod, a Greek poet, wrote:

I see no hope for the future of our people, if they are dependent on frivolous youth of today; for certainly all youth are reckless beyond words, and opinionated much beyond their years. When I was young, we were taught to be discreet and respectful of elders, but present youth want to outwit their parents and have the last say (Heziod in Lavrič et al., 2011, p. 5).

As revealed in the description above and many others, youth is sometimes preceived as being marked by a moral crisis of society and the loss of values, while young people are understood as a problem that can be solved with appropriate intervention. As in the past, adults today have many expectations related to youth, seeing children and young people as rescuers (Moss, 2008; Furedi, 2009), who can lead society out of the crisis of civilisation, the crisis of values and the crisis of economy. A similar generalized view of youth can also be identified in the present age.

The first view - the view of youth as a problem - can be recognised in sentences like: young people are narcissistic, egoistic, withdrawn, apathetic individuals and groups who are not too interested in what is going on around them. Such a view is primarily encoded in the interpretations that stem from a (critical) analysis of the ideology of consumer society, associated with permissive familial and institutional education, the lack or erosion of authority, lack of responsibility and commitment due to diminished authority, and a society in which pleasure becomes imperative rather than prohibited (Lasch, 2012; Kovač Šebart, 2015). A discourse built on the assumptions presented above, yet promoting authoritarian positions of power, is easily identified in Slovenia in (lay) anthropological, populist views on the socialisation of children and adolescents (e.g. Vuk Godina, 2011; Vodopivec Kolar, 2014), and certain psychotherapeutic discourses (e.g. Milivojević, 2012). Such lines of thought are especially prevalent in various manuals on upbringing (e.g. Juhant and Levc, 2011; Žorž, 2012).

The authors mentioned above feel that the problem should be solved by returning to the repressive, punishing and authoritarian moral education; they build their discourse on an 
over-simplified interpretation of the enlightened deontological paradigm, and an understanding of moral education that is best described by the quote discipline as a condition of freedom (Salecl, 2010). Deontological paradigm of morality, which in pedagogical theory can be traced back to Kant (1988), has its origins in the understanding of morality through universal criteria of justice (Rawls, 1971); criteria that envision the individual and the society as having a duty to act, based on the argumentation of the human reason (Kant, 1988). Education is thus seen as primarily aiming at the development of social cognitions enabling appropriate judgement. This view, however, has already been subjected to criticism (e.g. Kroflič, 2007). Building on Aristotle's philosophy (Aristotel, 2002), some contemporary authors (e.g. Kroflič, 2007; Kristjánsson, 2010; Jeznik, 2015) propose an aretaic paradigm, as an alternative to the deontological paradigm. Aretaic paradigm speaks about morality from the perspective of the shaping personality traits that come into being with the help of contextual sensitivity in real-life situations. The main aim of such views of moral education is the establishment of relationships and emotional response towards the shaping of a moral judgement that directs the actions of an individual (Kroflič and Smrtnik Vitulić, 2015; Štirn Janota, 2015).

Another view and the image of youth as rescuers can today be detected on two levels. Furedi (2009) identifies the first view on the level of various images of the child that are understood as inherently good. If children are given the chance to develop and thrive through moral education, they can grow up to be "moral regenerators of the nation" (Furedi, 2009, p. 11), a view held already by Rousseau (1959) in his pedagogical fiction Emile or On Education, and by supporters of progressive pedagogy at the beginning of the $20^{\text {th }}$ century. Today, the idea can be found in the background of the concepts of "child-centred education" (Furedi, 2009). Children, who are supposed to learn how to manage their emotions and solve problems appropriately during their childhood, are expected to apply this to their adulthood. The view builds on the romantic preception of a child, typical of more permissive educational views, which have also been closely examined and assessed in the Slovenian context (Kroflič, 1997; Kroflič, 2007).

Another example of youth being viewed as rescuers can be identified in the background of some of the neoliberal documents that have an indirect influence on the politics of dealing with various social groups. In one of the most important current initiatives of the strategy Europe 2020: A European Strategy for a Smart, Sustainable and Inclusive Growth (European Commission, 2010), which includes the initiative Youth and Mobility (ibid.), youth are represented as a social group that bears an important role in achieving the goals of the strategy related to the economic development of the state. ${ }^{2}$ The key factors of tapping into the potential of youth that are identified in the initiative are: providing youth with quality education and training, including youth in the job market and increasing the scope of mobility (ibid., p. 13). In the discussed and other similar strategic

2 Such views were already present in European Commission's White Papers: A new initiative for European youth 2002, while examining other levels of education, such as that of adults, authors came to similar findings (e.g. Mikulec, 2015). 
documents pertaining to the field of youth (compare: Resolucija o ..., 2013), the situation of today's youth is seen as unfavourable (high rate of unemployment etc.), while the same documents contain ideological speech of youth as rescuers. Despite the fact that a few years ago it appeared that youth are a burden to society as they were associated with high costs (Kuhar and Razpotnik, 2011), both society and the state recognised them as having potential and being the carriers of social development.

To sum up, the image of youth runs in two directions. On the one hand, young people are understood as having potential, while on the other hand they are seen as egoistic and narcissistic individuals disinterested in current social affairs. In the following paragraphs, we are going to portray how images of youth as a group are mirrored in the images of students enrolled in vocational education.

\section{IMAGES OF STUDENTS IN VOCATIONAL EDUCATION AND TRAINING}

In Slovenia, there is a low level of interest in vocational schools. Despite attempts to make vocational education programmes more appealing (Lovšin, 2015), reforms of professional education in the past decade (Skubic Ermenc, Mažgon and Štefanc, 2014; Skubic Ermenc and Mažgon, 2015) and some (often not properly thought-through) initiatives for the development of certain skills (e.g. entrepreneurship), personality traits and characteristics (innovativeness etc.), with which young people were to respond to the new, emerging needs of the job market (Cankar and Deutsch, 2015), it is nevertheless still assumed that vocational schools serve those adolescents, who fail to enrol into general or vocational education. Due to the scarcity of studies that would explore the image of students enrolled in Slovenian vocational education, we are going to analyse that image by examining two studies that highlighted this question. Proceeding from the data gathered in those studies, we are going to highlight the specific nature of the image of students enrolled in vocational education.

\section{The image of Students in Vocational Education}

Authors of the study Factors of Academic Success in Vocational Education ${ }^{3}$ (Flere, Klanjšek, Musil, Tavčar Krajnc, Kirbiš and Naterer, 2008) defined the profile of students as:

having a lower level of intellectual ability and success at school, more often attributing the cause for either their success or failure to circumstances than their own internal attributes, more likely to seek help within the family and circle of friends as well as school, exhibiting more problems in the learning process, posessing a more negative self-image and a lower level of satisfaction

3 Researchers conducted a survey on a representative proportion of secondary school students $(n=1413)$. Participants responded to two instruments. The first one was Pogačnik's Test of Abilities (Pogačnik, 1983 in Flere et al., 2008, p. 39), while the second one was a survey questionnaire (general questions on school success of participants in different stages of education, the social status and the shape of the family, attitude to school, variouos aspects of psychosocial and personality profile and different aspects of socialization) (see ibid., pp. 38-45). 
with school or attachment to school, coming from families with parents with a significantly lower level of education as well as a lower level of closeness to both their mother and their father. /.../ representing, in fact, a direct opposite of the profile of students in general or technical secondary schools. (Ibid, p. 126).

The examined study revealed a statistically significant difference in the level of success between students in vocational training and those in vocational education and general programmes of secondary school education. The found differences were especially conspicuous in the case of items relating to important socio-cultural or personal characteristics (ibid., p. 131). The image of students in vocational schools, as it is revealed based on the findings, is a problematic one, although not in the sense of the image of youth as rescuers or as a problem. As authors of the study found (ibid.), students who enrol in vocational schools, generally come from less supportive home environment (families with a lower socio-economic status, weaker cultural capital etc.). The factors in question bear an important influence on the choice of the educational path of students, while the influence of students themselves is marginal.

The above-mentioned findings point to a broader problem of vocational education in Slovenia, also supported by the current data about the employability of Slovenian youth. Despite the fact that, when examining the level of education of unemployed youth between the ages of 16 and $29^{4}$, the least represented group are those with a vocational level of education, ${ }^{5}$ while the trend of continuing increase in the percentage of unemployed youth aged 25-29 with a tertiary level of education is seen as the most problematic, the examination of the movement of youth on the educational vertical ladder reveals that approximately half of the whole generation of youth ${ }^{6}$ continue their path towards a higher level of education.

Statistical facts speak in favour of better employment prospects for youth with vocational education; nonetheless, there has been a continuing decrease in the percentage of youth enrolled in professional education in the past few decades (Medveš et al., 2008). In the recent years, the trend has slowly been changing. Consequently, we cannot assumer that all students who are enrolled in vocational education are going to be able to enter the job market after finishing their schooling. Data shows that young people wish to continue

4 In 2015, nearly 35 millions of youth aged between 16 and 29 in OECD were considered NEET, i.e. neither enrolled in the educational system neither employed (OECD Skills ..., 2015). In Slovenia, the percentage of unemployed youth in the age group 15-29 was $23.1 \%$, and the most numerous group were first-time job-seekers $(52.8 \%)$, followed by long-term unemployed $(33.6 \%)$. On average, unemployment in this group lasted for 12.4 months and in the period between 2009 and 2014, while long-term unemployment increased more than four times (Poročilo o razvoju, 2015, 52-56).

5 In June 2015, $24.8 \%$ of unemployed youth aged 16-29 had completed primary school, $18.4 \%$ had a professional education and $19.9 \%$ had a completed tertiary level of education. The least frequent level of education among unemployed youth was the level of professional education (Zaposlovanje mladih 2015, 2015).

6 Data on the enrollment of students in 2014/15 reveals that $47.7 \%$ of youth aged between 19 and 24 were enrolled in tertiary education (Vpis študentov v višješolsko in visokošolsko izobraževanje ..., 2015). 
their education. We can conclude that their wish to continue education does is not necessarily only the consequence of their thirst for knowledge or the wish for a higher level of education, but also a result of the lack of career opportunities on the job market (Kuhar and Reiter, 2012a, 218).

The trend is additionally supported by parents of adolescents. Findings obtained in the project Managing Educational Flows in Europe (GOETE) show that the highest educational aspirations aimed at a higher (at least tertiary) level of education among all the countries participating in the project are to be found among parents in Slovenia (Ule, 2013b; Ule, 2015, p. 35). Based on the obtained data, Ule highlights the engagement of students' families and their influence on the educational flows of children and adolescents. She defines the engagement of parents as a new factor of social differentiation of children and adolescents, and highlights "that psychosocial factors that enable the reproduction of deprived youth (e.g. disengagement of parents in their children's schooling, disinterest in their children, poor cultural capital of parents, negative experiences with school) are often a consequence of social, economic and cultural deprivation of the previous generation" (ibid., p. 44). School should play an important role in the breaking of that circle, especially in the sense of correcting the existing social differences.

The study Factors of Academic Success in Vocational Education (Flere et al., 2008) and its findings, however, reveals the opposite (i.e. disengagement of the environment in case of youth in vocational schools) - hence, these findings are important from a broader social perspective, relating to the meaning of vocational education. It would appear that vocational education in its present form additionally deepens the existing injustices in society and even prolongs the path achieving desired education for a certain group of students.

\section{The image of Students in Vocational Education and Training as Seen Through the Eyes of Students and Teachers}

To further outline the social construct of youth, let us examine the results of a study entitled Implementation of Rules on School Order and Educational Concept in Vocational Education and Training ${ }^{7}$ (Kroflič et al., 2009; Jeznik, 2013). Students and teachers responded to a number of questions related to the general image of youth. ${ }^{8}$ Analysis of responses revealed statistically significant differences between responses of teachers and students (ibid., p. 152). Below are the most significant and most telling ones:

7 The survey that was a part of the study in question included 41 vocational schools in Slovenia. The questionnaire included 2,934 students (55.9\% male and $44.1 \%$ female) enrolled in the 1 st year of short-term vocational training, 1st and 2nd year of vocational secondary training, 1st and 3rd year of technical secondary education and 4th year of vocational-technical education. The study included 491 teachers $(35.2 \%$ were male and $64.8 \%$ were female) with an average of 15 years of service. More information on the study can be obtained at: http://www.cpi.si/files/cpi/userfiles/RazvojniProjekti/Metodologija1.pdf.

8 Students and teachers responded to questions on a Likert-type scale. Items were assessed on a 4-point scale ( 1 to 4 ) where 1 was defined as "not at all important", 2 as "somewhat important", 3 as "important" and 4 as "very important". The obtained data was analysed on the level of descriptive and inference statistics using SPSS. Hypotheses were tested by using the $\chi^{2}$ test. 
- Teachers have a higher rate of agreement with the statement students are self-absorbed, despite the fact that more than half of the teachers believe that this is not generally true.

- $\quad$ Students have a higher rate of agreement with the statement students are willing to. participate in social life. The majority of teachers who agree with the statement teach at lower vocational education level and teach practical skills.

- $\quad$ Students have a higher rate of agreement with the statement that they are dealing with important life questions (e.g. employment, family).

- Students have a higher rate of agreement with the statement that they are of open and free spirit.

- $\quad$ Students have a higher rate of agreement with the statement that they are generally disciplined and well-mannered, motivated for learning and decent.

- Students have a higher rate of agreement with the statement that they are responsible (ibid.).

Students' opinions about themselves differ from teachers' assessment of the general image of students. Teachers see students as self-absorbed and not actively engaged in social life, whereas students hold a different opinion. Students, on the other hand, agree with statements describing them as having an open-minded, free spirit, disciplined, well-mannered, responsible, motivated for learning and capable. Teachers' agreement with the statements in question is significantly lower (ibid, pp.152-160). Students' mentors were not included in the study, however, we may hypothesise that they play an active role in the co-creation of images of students they encounter. The latter plays an important role from the perspective of the role of the mentor in the pedagogical process. In order for quality mentoring (Govekar-Okoliš and Kranjčec, 2013), attention needs to be paid to the additional knowledge that mentors would need to gain.

Proceeding from the findings we can conclude that teachers potentially underestimate students of vocational education and training in their assessments. Such a stance is undoubtedly reflected in their educational actions that divert from the goals of education and training. Even if students hold an unrealistic self-image, findings of the study serve as a warning that the issue should be further examined. Simplification of findings may serve to strengthen various ideologically coloured social images of students enrolled in vocational training and education as a problem. Such judgements are additionally depended through the teachers' assessments and their seeing of the students as incompetent, undisciplined, having poor manners, low motivation and lacking responsibility. Taking into the account the degree of socially desired answers (Ellingson, Smith and Sackett, 2001), which we have not measured specifically in the present study, a warning is required, since that is the only way to avoid self-fulfilling prophecy (Gomboc, 2011) which may occur when an individual, who is constantly given a feeling of inferiority, accepts such a role. Underestimating the students enrolled in vocational education and a misconstrued recognition due to a choice of a specific educational path leads to students being denied the responsibility and prevented from the formation of a more realistic self-image (Jeznik, 2015). 


\section{Value Orientation of Students in Vocational Education and Training}

The image of students enrolled in vocational schools and training will be further examined proceeding from data about their value-orientations. It must be noted, however, that such findings may be interpreted differently. M. Ule (2008, 2013a) brings attention to the fact that interpretations may vary. She finds that in the background of the values which give the impression of egoism and narcissism, ${ }^{9}$ we may often find the "process of selfexplanation that includes looking for new social ties in the family, in friendships, at work and in public" (Ule, 2013a, p. 94). At the end of 1990s Beck et al. (1997) came to similar conclusions. In the collection Kinder der Freiheit (ibid.), young people were labelled as children of freedom who rebel against duties, without a cause. The collection at the same time warned that people are suffering due to the fact that freedom is not compatible with traditional social structures (e.g. the question of how to combine traditional authority of the family with a newly-found freedom of men and women). Children of freedom are supposedly already following the so-called seeker's morale, creating links between what seems to be mutually exclusive: self-actualisation and being there for others (ibid.). Wuthnow (in Beck, 1997.) calls the phenomenon altruistic individualism, which is best expressed as the following: those who live for themselves, need to live socially (ibid, p. 19). The author stresses the increased importance which young people place onto relations with their loved ones, with their peers and members of different generations, and which further also includes an increased concern in the fields of ecology and phenomena in virtual worlds. Ule (2013a) speaks of a so-called new ethics of everyday life emerging among young people, reflected in their engaged interest in the world around them, and reconciliation of seemingly opposite concepts, such as individualism and altruism (taking care of oneself while taking care of others).

Different researchers of youth and value-orientations among young people (Ule and Miheljak, 1995; Inglehart, 1997; Miheljak, 2002; Ule, 2008; Lavrič et al., 2011; Kuhar and Reiter, 2012b; Kuhar and Reiter, 2014) seem to agree on the thesis about new post-materialistic values emerging among young people and replacing old, materialistic values. Inglehart (ibid; Lavrič et al., 2011, p. 10) drew on a macro-analysis of findings obtained in longitudinal empirical studies world-wide (project World Values Survey in ibid.) found two key value-culture dimensions: self-expression versus survival, and secular-rational authority versus traditional authority. The shift from the traditional to the secular-rational authority is linked to modernisation, while the shift from survival to self-expression has to do with post-modernisation as a substitution of material goals with expressive or

9 Ambiguity in the interpretation of statistical data can, for example, be found among authors of the study Youth 2010 (Lavrič et al., 2011) and in the interpretations drawn by e.g. V. Vuk Godina (2011). Findings by Lavrič et al. (2011, pp. 355-266) can be summed up by the following quote: "The psychological portrait of Slovenian Youth does not show youth being spoilt, deviant, apathetic or living in an 'existential vacuum'. The latter is negated by Slovenian youth's low results on alienation. Although we did not examine it systematically, based on the indicators used, we can conclude that the presence of pathological narcissism among youth in Slovenia is not a cause for concern." (ibid., p. 366) On the other hand, V. Vuk Godina uses data from the same research Youth 2010 in developing a thesis about the increase of narcissism among youth in Slovenia (Godina, 2011). 
psychological ones. Compared with the findings of the research Implementation of Rules on School Order and Educational Concept in Vocational Education and Training, where the sample consisted of students in vocational education and training (Jeznik, 2013, p. 162 ), we can reach the conclusion that there was indeed a shift in value orientations from materialistic and career-focused ones to more personal and post-materialistic ones. Values with a strong ideological background (money, leadership, having power over others) remain at the bottom of the scale, while values pertaining to individuals stay at the top of the scale (health, family and friendship) (Ibid.).

We can conclude that the value orientation of students in vocational education and training does not differ much from the value orientation of students in general secondary education. Students in vocational education and training may have a poorer adaptation (compared to the secondary school students), relating to demands of the school system as such (regular school attendance, classes being led ex cathedra, written and oral assessment etc.), which is why it would be worth exploring some alternative ways of obtaining either vocational or general secondary education. Medveš (2013) warns that the current hybrid model of vocational education, based on a combination of academic type of education and apprenticeship, has led to the vocational education becoming the weakest link in the educational vertical ladder in Slovenia. Flere et al. (2008) came to similar conclusions. In the case of various paths to vocational education being trimmed, this would most likely even lower the motivation of young people to enrol in vocational schools, especially students who would like to enter the job market sooner and those students who would like to obtain training for some rare professions as well as those who (for various reasons) cannot or will not be included in the general way of obtaining vocational education.

\section{CONCLUSION}

Our findings are based on studies that examined the image of vocational school students, and reveal that the academic success of students in vocational schools differs from students in vocational training and general education programmes. Differences in academic success were significantly related to the influence of the students' environments (Flere et al., 2008; Flere, 2010), and vocational education in its present form was found to further reproduce and deepen differences among students instead of minimizing them; a finding that concurs with what has been found in the previous studies (Medveš et al., 2008). Differences among students enrolled in various educational programmes are, moreover, maintained through the uncritical reproduction of ideological images of adolescents, which becomes especially problematic due to the views held by teachers, who perceive students as undisciplined, indecent and lacking motivation. Instead of doing the opposite, such views become additional agents in contributing to the inferior position of vocational education in the society. Furthermore, the analysed studies revealed no significant differences between value orientation of adolescents as a general group and those of the students in vocational schools. Both groups relate more closely to the new, post-materialistic values (health, family and friendship), which are replacing the old values, such as money, leadership, power etc. 
The findings of our study are topical for various reasons. The image of students enrolled in vocational education can be understood as a result of educational politics, with this very image of students additionally deepening the discussed problems of vocational education (low numbers of enrolled students compared to other levels of secondary education; the question of education-discipline; deepening of social injustices). Based on the above-discussed findings, we cannot confirm the existence of a social and psychological segregation of the vocational education in Slovenia. The discussed problems are typical not only of Slovenia, but are also present in other European countries (Flere, 2010, p. 132; OECD, 2016). However, educational politics that only serves to additionally intensify the problematic situation of the vocational education is clearly misguided. On the one hand, vocational schools in Slovenia seem to have no perspective within the existing system of secondary education, ${ }^{10}$ while on the other hand, some European documents uncritically direct member states towards improving the image of vocational education, and representing it as one of the answers for the current state of youth in the broader society (e.g. lowering the rate of youth unemployment through promoting the acquiring of the status of an apprentice in a dual system ${ }^{11}$ ). Apprenticeship is portrayed as a magic wand that could be applied to resolve the problems of employability of youth, despite the fact that students tend to continue climbing the educational vertical ladder. This leads us to the conclusion that the existing system of vocational education only serves to prolong the path towards achieving the desired level of education for some students, and that the wish to find employment after completed formal education is the main aim of the apprenticeship. When analysing the factors that present an important base for the successful introduction of apprenticeship in Slovenia, researchers should also analyse the images of students, and that of those images play in the mentoring work during the time when students in vocational education come in contact with the employers. Based on the existence of various types of mentoring, an answer could perhaps be found in the creation of special mentoring groups, which would aim at correcting the deficits that arise due to the unfavourable influence of students' environment.

\section{REFERENCES}

Althusser, L. (2000). Izbrani spisi. Ljubljana: Založba /*cf.

Apple W. M. (1992). Šola, učitelj in oblast. Ljubljana: Znanstveno in publicistično središče.

Aristotel. (2002). Nikomahova etika. Ljubljana: Slovenska matica.

Beck, U. (Ed.). (1997). Kinder der Freiheit. Suhrkamp: Frankfurt am Main.

Boyden, J. and Bourdillon, M. (2014). Growing up in Poverty: Findings from Young Lives, Basingstoke: Palgrave Macmillan.

10 Krek and Mertljak (2011) suggest a radical reorganization of the three-year vocational training into a four-year training.

11 Analyses of various European educational systems show that the countries with the least problems with youth employability are those with a well-developed system of apprenticeship (e.g. Denmark, Germany and Austria) (Krek and Mertljak, 2011). 
Cankar, F., Deutsch T. (Eds.) (2015). Mladi, šola in izzivi prihodnosti: razvoj ustvarjalnosti in inovativnosti kot sestavin podjetniške naravnanosti in spretnosti v osnovni šoli. Ljubljana: Zavod RS za šolstvo.

Dolby, N. and Rizvi, F. (2008). Introduction: Youth, Mobility and Identity. In N. Dolby, and F. Rizvi (Eds.), Youth Moves: Identities and Education in Global Perspective (pp.1-15). New York, London: Routledge.

Ellingson, J. E., Smith, D. B. and Sackett, P. R. (2001). Investigating the Influence of Social Desirability on Personality Factor Structure. Journal of Applied Psychology, 86(1), 122-133.

European Commission. (2010). Europe 2020. A strategy for Smart, Sustainable and Inclusive Growth. Retrieved from http://ec.europa.eu/eu2020/pdf/COMPLET\%20EN\%2059 BARROSO $\% 20 \% 20$ \%20007\%20-\%20Europe\%202020\%20-\%20EN\%20version.pdf.

Flere, S., Klanjšek, R., Musil, B., Tavčar Krajnc, M., Kirbiš, A. and Naterer, A. (2008). Dejavniki šolske uspešnosti v poklicnem izobraževanju: poročilo o rezultatih raziskave. Ljubljana: Pedagoški inštitut.

Flere, S. (Ed.). (2010). Kdo je uspešen v slovenskih šolah? Ljubljana: Pedagoški inštitut.

Furedi, F. (2009). Socialisation as Behaviour Management and the Ascendancy of Expert Authority. Amsterdam: Vossiuspers UvA.

Gomboc, S. (2011). Samouresničujoča se prerokba: pojav in implikacije. Psihološka obzorja, 20(2), 83-105.

Govekar-Okoliš, M. and Kranjčec, R. (2013). Uspešnost mentorstva v izobraževanju starejših odraslih. The Andragogic Perspectives, 19(3), 80-91.

Inglehart, R. (1997). Modernization and Postmodernization: Cultural, Economic, and Political Change in 43 Societies. Princeton, Chichester: Princeton University Press.

Jeznik, K. (2013). Oblikovanje identitete mladih skozi sodobne koncepte vzgoje (Doktorska disertacija). Filozofska fakulteta, Ljubljana.

Jeznik, K. (2015). From the Acknowledgment to the Recognition of Children's and Adolescents' Identity. Journal of Contemporary Educational Studies, 66(1), 28-45.

Juhant, M. and Levc, S. (2011). Varuh otrokovih dolžnosti: ali nehajte se ukvarjati z otrokovimi pravica$m i$ ! Mavčiče: Čmrlj, komuniciranje in ustvarjalnost.

Kant, I. (1988). O pedagogiki. Problemi: revija za kulturo in družbena vprašanja, 26(11), 147-158.

Kodelja, Z. (2014). The ideology of Evaluation and the Pedagogic Discourse. In V. Pobežin (Ed.), Drugo pedagoškega diskurza (pp.179-190). Ljubljana: Pedagoški inštitut.

Kovač Šebart, M. (2015). How to Evaluate and Judge when the Moral-Educational Dimension of Instruction is Concerned? Review of European studies, 7(11), 138-146.

Krek J. and Metljak M. (Eds.). (2011). Bela knjiga o vzgoji in izobraževanju v Republiki Sloveniji. Ljubljana: Ministrstvo za šolstvo in šport.

Kristjánsson, K. (2010). The Self and Its Emotions. New York: Cambridge University Press.

Kroflič, R. (1997). Avtoriteta v vzgoji. Ljubljana: Znanstveno in publicistično središče.

Kroflič, R. (2005). Disciplina in/ali vzgoja v javni šoli oziroma vrtcu. Journal of Contemporary Educational Studies, 56/122(4), 6-13.

Kroflič, R. (2007). Vzgoja za odgovornost onkraj razsvetljenske paradigme: od razvoja odgovora-zmožnosti k spoštljivemu odnosu in razvoju etične zavesti. Journal of Contemporary Educational Studies, 58 (pos. izd.), 56-71.

Kroflič, R. and Smrtnik Vitulić, H. (2015). The Effects of the Comprehensive Inductive Educational Approach on the Social Behaviour of Preschool Children in Kindergarten. CEPS journal: Center for Educational Policy Studies Journal, 5(1), 53-69. 
Kroflič, R., Mažgon, J., Klarič, T., Jeznik, K., Štirn Janota, P., Štirn Koren, D., Vončina, V., Ermenc, K. S., Lenič, Š., Makovec, D., Rutar, V. and Peček, M. (2009). Ali poklicne in strokovne šole potrebujejo vzgojni koncept? Ljubljana: Center RS za poklicno izobraževanje.

Kuhar, M. and Razpotnik, Š. (2011). Okviri in izzivi socialnega dela v Sloveniji. Ljubljana: Pedagoška fakulteta.

Kuhar, M. and Reiter, H. (2012a). Frozen Transitions to Adulthood of Young People in Slovenia? Sociologija, 54(2), 211-226.

Kuhar, M. and Reiter, H. (2012b). Parental Authority in Flux: A Qualitative Exploration of Manifestations of Power in Parent - Child Relationships. Revija za sociologiju, 42(3), 277-304.

Kuhar, M. and Reiter, H. (2014). Leaving Home in Slovenia: A Quantitative Exploration of Residential Independence Among Young Adults. Journal of adolescence, 37(8), 1409-1419.

Lasch, C. (2012). Kultura narcisizma: ameriško življenje v času zmanjšanih pričakovanj. Ljubljana: Mladinska knjiga.

Lavrič, M., Flere, S., Tavčar Krajnc, M., Klanjšek, R., Musil, B., Naterer, A., Kirbiš, A., Divjak, M. and Lešek, P. (2011). Mladina 2010. Družbeni profil mladih v Sloveniji. Ljubljana: Ministrstvo za šolstvo in šport, Urad RS za mladino; Maribor: Aristej.

Lovšin, M. (2015). The (Un)Attractiveness of Vocational and Technical Education: Eheoretical Background. CEPS journal: Center for Educational Policy Studies Journal, 4(1), 101-120.

Medveš, Z. (2013). Poklicno izobraževanje je pred desetletjem skrenilo na slepi tir. Journal of Contemporary Educational Studies, 64(1), 10-30.

Medveš, Z., Kodelja, Z., Mažgon, J., Ermenc, K.S., Peček, M., Lesar, I. and Pevec Grm, S. (2008). Contribution of Vocational Education and Training to Equity and Social Inclusion. Journal of Contemporary Educational Studies, 59(5), 74-94.

Miheljak, V. (Ed.). (2002). Mladina 2000. Slovenska mladina na prehodu v tretje tisočletje. Ljubljana: Ministrstvo za šolstvo, znanost in šport, Urad Republike Slovenije za mladino in Založba Aristej.

Mikulec, B. (2015). Concepts of Knowledge, Subjectivity and Adult Education in European Adult Education Policy. Journal of Contemporary Educational Studies, 66(4), 48-63.

Milivojević, Z. (2012). Priznati je treba, da je s šolskim sistemom nekaj hudo narobe. Didakta, 21(151), 4-8.

Moss, P. (2008). Toward a New Public Education: Making Globalization Work for Us All. Child development perspectives, 2(2), 114-119.

OECD skills outlook 2015 : youth, skills and employability (2015). Paris : OECD. Retrived from http://www.oecd-ilibrary.org/education/oecd-skills-outlook-2015_9789264234178-en;jsessionid=1blhv3665m7fw.x-oecd-live-02.

OECD (2016). Low-Performing Students: Why They Fall Behind and How to Help Them Succeed, PISA.

Paris: OECD Publishing. Retrieved from http://www.keepeek.com/Digital-Asset-Management/ oecd/education/low-performing-students_9789264250246-en\#page1.

Poročilo o razvoju 2015 (2015). UMAR: Ljubljana. Retrieved from http://www.mddsz.gov.si/fileadmin/ mddsz.gov.si/pageuploads/dokumenti_pdf/zaposlovanje/Smernice_APZ_2016_2020_final.pdf.

Rawls, J. (1971): A Theory of Justice. Cambridge: Belknap Press.

Resolucija o nacionalnem programu za mladino 2013-2022 (ReNPM13-22) (2013). Retrieved from http://www.ursm.gov.si/fileadmin/ursm.gov.si/pageuploads/pdf/Nacionalni_program_za_mladino/ resolucija_o_npm/Recolucija_o_NPM.pdf.

Rousseau, J. J. (1959). Emil ali o vzgoji. Ljubljana: Državna založba Slovenije.

Salecl, R. (2010). Disciplina kot pogoj svobode. Ljubljana: Krtina. 
Schiro, M. S. (2013). Curriculum Theory Conflicting Visions and Enduring Concerns. Boston: College. Skubic Ermenc, K., Mažgon, J. and Štefanc, D. (2014). The competence-based didactic approach in initial vocational education. Zbornik Instituta za pedagoška istraživanja, 46(2), 509-526.

Skubic Ermenc, K. and Mažgon, J. (2015). Bureaucratisation of the teaching profession in decentralised vocational education : the case of Slovenia, Europe. International education studies, 8(5), 12-20.

Štirn Janota, P. (2015). The Inductive Approach on the Path from Prosocial to Ethical - a Case Study. Journal of Contemporary Educational Studies, 66(1), 46-69.

Ule, M. (2008). Za vedno mladi? Socialna psihologija odraščanja. Ljubljana: Fakulteta za družbene vede.

Ule, M. (2013a). Spreminjanje vrednot v sodobnih življenjskih potekih. In A. Bjelčevič (Eds.), Etika v slovenskem jeziku, literaturi in kulturi: zbornik predavanj (pp. 89-96). Ljubljana: Znanstvena založba Filozofske fakultete.

Ule, M. (2013b). Governance of Educational Trajectories in Slovenia: Dilemmas and Contradictions. Annales, 23(2), 291-302.

Ule, M. (2015). The Role of Parents in Children's Educational Trajectories in Slovenia. Journal of Contemporary Educational Studies, 66(1), 10-27.

Ule, M. and Miheljak, V. (Eds.) (1995). Prihodnost mladine. Ljubljana: DZS.

Usposabljanje mentorjev dijakom oziroma študentom za praktično usposabljanje oziroma izobraževanje v podjetjih (2016). Retrieved from http://www.cpi.si/files/cpi/userfiles/IP/PROGRAM_MENTORJ__ SPLOSNI_DEL_S_KATALOGI_22-4-2011.doc.

Usposabljanje mentorjev PUD in PRI (2012). Celje: Šolski center Celje. Retrieved from http://www. mizs.gov.si/fileadmin/mizs.gov.si/pageuploads/podrocje/ss/Gradiva_ESS/Usposabljanje_mentorjev/MENTORJI_1Usposabljanje_mentorjev_PUD_PRI.pdf.

Vodopivec Kolar, K. (2014). Anthropological Analysis of Narcissism in Selected Slovenian Primary Schools. In V. Pobežin (Eds.), Drugo pedagoškega diskurza (p.p. 147-168). Ljubljana: Pedagoški inštitut.

Vpis študentov v višješolsko in visokošolsko izobraževanje, Slovenija, študijsko leto 2014/15 (2015). Ljubljana: Statistični urad RS. Retrived from http://www.stat.si/StatWeb/prikazi-novico?id=5015\&idp $=9 \&$ headerbar $=7$.

Vuk Godina, V. (2011). Narcisizem kot nevidna značilnost in dimenzija vedenje slovenske mladine. In A. Naterer (Eds.), Mladi 2010 (p.p. 125-143). Maribor: Subkulturni azil.

Zakon o poklicnem in strokovnem izobraževanju (2006). Uradni list RS, 79. Retrived from http://www. uradni-list.si/1/objava.jsp?urlid=200679\&stevilka=3449.

Zaposlovanje mladih 2015 (2015). Mladinski svet Slovenije. Retrieved from http://www.mss.si/datoteke/ dokumenti/Zaposlovanje_mladih_MDM_2015.pdf.

Žorž, B. (2012). Razvajenost - rak sodobne vzgoje. Celje: Društvo Mohorjeva družba. 